\title{
BMJ Open A cross-sectional study of the association of age, gender, education and economic status with individual perceptions of governmental response to COVID-19
}

\author{
Jeffrey V Lazarus (D) , ${ }^{1}$ Adam Palayew, ${ }^{2}$ Kenneth Rabin, ${ }^{3}$ Katarzyna Wyka, ${ }^{3}$ \\ Sonia Hajo, ${ }^{4}$ Scott Ratzan, ${ }^{3}$ Jonathan Fielding, ${ }^{5}$ Ayman El-Mohandes ${ }^{3}$
}

To cite: Lazarus JV,

Palayew A, Rabin K, et al. A cross-sectional study of the association of age, gender, education and economic status with individual perceptions of governmental response to COVID-19. BMJ Open 2021;11:e047310. doi:10.1136/ bmjopen-2020-047310

- Prepublication history for this paper is available online. To view these files, please visit the journal online (http://dx.doi. org/10.1136/bmjopen-2020047310).

Received 25 November 2020 Revised 01 February 2021 Accepted 24 February 2021

Check for updates

(C) Author(s) (or their employer(s)) 2021. Re-use permitted under CC BY-NC. No commercial re-use. See rights and permissions. Published by BMJ.

For numbered affiliations see end of article.

Correspondence to Dr Jeffrey V Lazarus; jeffrey.lazarus@isglobal.org

\section{ABSTRACT}

Objective We assessed the impact of key population variables (age, gender, income and education) on perceptions of governmental effectiveness in communicating about COVID-19, helping meet needs for food and shelter, providing physical and mental healthcare services, and allocating dedicated resources to vulnerable populations.

Design Cross-sectional study carried out in June 2020. Participants and setting 13426 individuals from 19 countries.

Results More than $60 \%$ of all respondents felt their government had communicated adequately during the pandemic. National variances ranged from $83.4 \%$ in China down to $37.2 \%$ in Brazil, but overall, males and those with a higher income were more likely to rate government communications highly. Almost half (48.8\%) of the respondents felt their government had ensured adequate access to physical health services (ranging from $89.3 \%$ for Singapore to $27.2 \%$ for Poland), with higher ratings reported by younger and higher-income respondents. Ratings of mental health support were lower overall $(32.9 \%$, ranging from $74.8 \%$ in China to around 15\% in Brazil and Sweden), but highest among younger respondents. Providing support for basic necessities of food and housing was rated highest overall in China (79\%) and lowest in Ecuador (14.6\%), with higher ratings reported by younger, higher-income and better-educated respondents across all countries. The same three demographic groups tended to rate their country's support to vulnerable groups more highly than other respondents, with national scores ranging from around $75 \%$ (Singapore and China) to $19.5 \%$ (Sweden). Subgroup findings are mostly independent of intercountry variations with $15 \%$ of variation being due to intercountry differences. Conclusions The tendency of younger, better-paid and better-educated respondents to rate their country's response to the pandemic more highly, suggests that government responses must be nuanced and pay greater attention to the needs of less-advantaged citizens as they continue to address this pandemic.

\section{INTRODUCTION}

The COVID-19 pandemic continues to surge, with more than 100 million cases and
Strengths and limitations of this study

- At the time it was carried out, this was the first large, multicountry study, to our knowledge, to assess to what degree respondents' age, gender, economic level and education are associated with perceptions of governmental effectiveness in meeting essential public health needs during the COVID-19 pandemic.

- The stage of the pandemic in the respondent's country, as well as the respondent's personal experience with access to and quality of healthcare services, may have influenced the perceived effectiveness of government response to COVID-19.

- Differences in the forms or types of government that exist at national, regional and local levels in the 19 countries could make intercountry comparisons difficult to interpret.

- The samples we surveyed may not adequately represent the most vulnerable populations in each country, as they would be less likely to be able to participate in research of this type.

- This study is cross-sectional and was analysed descriptively, thus the reported associations cannot be interpreted causally.

2.1 million deaths reported as of January 2021. ${ }^{1}$ Transmission of SARS-CoV-2 and the severity of its impact on the population have been attributed to various socioecological factors, such as access to healthcare and technology, infrastructure, sustainable basic economic needs, variation in population demographics and implementation of protection measures. ${ }^{2-6}$ National responses to the pandemic continue to vary, ${ }^{78}$ with few countries taking all of the evidence-based actions needed to control the spread of the virus. ${ }^{9-12}$ Critical ongoing challenges to an effective governmental response include accurate risk assessment and reporting on viral spread, ${ }^{13-16}$ adequate surveillance of cases 
when confinement measures are reduced or lifted, ${ }^{17} 18$ and rising incidence and mortality where strong containment measures were not applied. ${ }^{19} 20$

Country-level decision-making is paramount to the COVID-19 response, but factors such as gender, age, education level and socioeconomic status may influence an individual's capacity to make health-related decisions, perceive risk, access preventive measures and adopt protective behaviours. ${ }^{21} 22$ Moreover, mixed messages concerning the threat, including the severity of the virus, may provoke strong emotional responses, particularly fear and anxiety, which shape an individuals' sense of self-efficacy in adopting the most favourable choices for themselves and/or their families. ${ }^{23}$

In a recently published paper describing how the general population in 19 high-burden countries scored their governments' response to the first wave of the pandemic, trust was correlated with better scores. ${ }^{6}$ In this paper, we focus on the associations of four key demographic variables among over 13000 individual respondents in the same 19-country study. Distinctly from their country's level of economic development and governance structure, these respondents represent a wide range of demographic groups, which are examined independently to determine their association with perceptions of government stewardship, service provision and communication during the pandemic. Given previous studies reporting the ways in which the COVID-19 pandemic has impacted different segments of the population, ${ }^{24-28}$ we conducted a post-hoc analysis of the COVID-SCORE data ${ }^{6}$ to evaluate to what degree age, education, economic level and gender in populations across national boundaries are associated with their perceptions of five aspects of governmental effectiveness: communicating about the pandemic itself and ways to help control it, providing assistance in meeting needs for food and shelter, addressing physical and mental healthcare needs and allocating resources to support populations with special needs, such as the chronically ill, the elderly, the incarcerated and others with special needs.

\section{METHODS}

We analysed five questions from the COVID-SCORE study pertaining to personal perceptions of one's country's COVID-19 response. ${ }^{6}$ In that survey, participants responded to a total of 22 items, which included the 10 COVID-SCORE-10 items and standard demographic questions regarding age, gender, level of education and household income.

\section{Study participants}

The survey was fielded in 19 high-burden countries: Brazil, Canada, China, Ecuador, France, Germany, India, Italy, Mexico, Nigeria, Poland, Russia, Singapore, South Africa, South Korea, Spain, Sweden, the UK and the USA. The 19 countries selected were either among the 25 countries with the highest reported numbers of COVID-19 cases at the time the study was launched (12 June 2020) or, to ensure geographical representation, had the most cases in a World Health Organization (WHO) region.

Participants were recruited by Emerson College Polling through international online panel providers: Dynata provided 7423 respondents across all 19 countries; Opinion Access provided 3293 respondents from 14 countries; Survey Monkey provided 1941 responses from 12 countries; and Amazon MTurk provided 762 respondents from eight countries. On initial registration, respondents' identities were verified using internet protocol (IP) addresses, as were their mobile phone numbers to ensure that each participant was real and unique. Participants were recruited for the panels via a variety of methods, including online, by telephone and through direct mail solicitation.

\section{Random stratified sampling}

Each country was divided into regions based on city/ town, province or state unit of analysis. Strata were established by age, gender and level of education. The number of participants who could enrol in each of these strata was calculated to reflect the distribution in the general population based on census/survey estimates provided by the World Bank and Central Intelligence Agency (CIA) World Factbook. Data were weighted by strata with each stratum requiring a minimum of 50 participants. Further methodological details are described elsewhere. ${ }^{6}$

\section{Data collection}

Survey data were collected between 16 June 2020 and 20 June 2020 from an online panel of 13426 respondents aged 18 years and older from 19 countries, ranging between 619 and 773 participants per country. We examined the response to five questions from the 22 items collected:

1. 'The government helped me and my family meet our daily needs during the COVID-19 epidemic in terms of income, food and shelter';

2. 'The government communicated clearly to ensure that everyone had the information they needed to protect themselves and others from COVID-19, regardless of socioeconomic level, migrant status, ethnicity, or language';

3. 'The government made sure we always had full access to the healthcare services we needed during the epidemic';

4. 'The government provided special protection to vulnerable groups at higher risk such as the elderly, the poor, migrants, prisoners and the homeless during the COVID-19 epidemic';

5. 'The government provided mental health services to help people suffering from loneliness, depression and anxiety caused by the COVID-19 epidemic'.

All of the responses to these five questions were recorded on a 5-point Likert scale (completely disagree to completely agree). Data for age and income were collected through open text fields. Age was coded into 
three categories: 18-29, 30-60 and 61 years and older. Income was categorised as US\$0-8/day, US\$8-US\$32/ day and US\$32+/day for comparison on an absolute scale and were based on the Gapminder Institute income levels. ${ }^{29}$ Education was categorised into low, medium, high and very high groups. Participants who did not finish a secondary education (high school) were categorised as 'low'; those who had completed secondary, vocational, technical, professional associate or a high school degree were categorised as 'medium'; those who had completed a tertiary or bachelor's degree were categorised as 'high'; and those who had done postgraduate work were categorised as 'very high'. Gender was categorised as male or female.

\section{Ethics statement}

This study was approved by Emerson College, USA (Institutional Review Board (IRB) protocol number 20-023 F-E6/12) with an expiration date of 11 June 2021. The online questionnaire was administered by Emerson College to gather information from respondents after obtaining their written, informed consent about the survey and this project. Equitable compensation per survey was applied (US $\$ 2$ per complete survey for Mturk data and increased up to US\$3 in some countries) regardless of country being polled to comply with ethical compensation standards. No personally identifiable information was collected or stored.

\section{Patient and public involvement}

Patients or the public were not involved in the design, conduct, reporting or dissemination plans of our research.

\section{Analysis}

We analysed the distribution of the responses to the questions for the entire dataset. We then reported the results for five sets of univariate and multivariable regressions: one for each of the five questions. We also present a set of multilevel regressions with random intercepts to account for clustering of observations in countries. The variance partition coefficient (VPC) was reported to quantify the proportion of the total observed individual variation in the outcomes that is attributable to intercountry differences. We used logistic regression and defined the outcome as 1 if a respondent answered, 'completely agree' or 'somewhat agree' and 0 if the respondents answered anything else. The independent variables were the four demographic variables: age, gender, income and education. The reference groups were: age 18-29, low income, low education and female.

\section{RESULTS}

We analysed the data from 13426 individuals from 19 countries. Overall, $53.4 \%$ were female and $55.4 \%$ were aged $30-60$. About a third $(36.3 \%)$ had a university degree and $63.3 \%$ earned above US\$32 a day (table 1 ).
Table 1 Descriptive breakdown of data on demographics, and responses to the five selected questions ( $n=13423)$

N $\%$

Demographic characteristic

Gender

\begin{tabular}{|c|c|c|}
\hline Female & 7171 & 53.4 \\
\hline Male & 6127 & 45.6 \\
\hline NA & 125 & 0.9 \\
\hline \multicolumn{3}{|l|}{ Income level } \\
\hline US\$0-US\$8 per day & 1287 & 9.6 \\
\hline US\$8-US\$32 per day & 3011 & 22.4 \\
\hline US\$32+ & 8495 & 63.3 \\
\hline NA & 630 & 4.7 \\
\hline \multicolumn{3}{|l|}{ Education level } \\
\hline Less than high school (low) & 3830 & 28.5 \\
\hline High school and some college (medium) & 4691 & 34.9 \\
\hline Bachelor (high) & 3694 & 27.5 \\
\hline Postgraduate (very high) & 1177 & 8.8 \\
\hline NA & 31 & 0.2 \\
\hline \multicolumn{3}{|l|}{ Age group } \\
\hline $18-29$ & 4022 & 30.0 \\
\hline $30-60$ & 7442 & 55.4 \\
\hline $61+$ & 1959 & 14.6 \\
\hline \multicolumn{3}{|l|}{ Perceptions of COVID-19 response } \\
\hline \multicolumn{3}{|c|}{$\begin{array}{l}\text { The government helped me and my family meet our daily needs } \\
\text { during the COVID- } 19 \text { epidemic in terms of income, food and shelter }\end{array}$} \\
\hline Completely agree & 1681 & 12.5 \\
\hline Somewhat agree & 3649 & 27.2 \\
\hline Neutral/no opinion & 2890 & 21.5 \\
\hline Somewhat disagree & 2201 & 16.4 \\
\hline Completely disagree & 3002 & 22.4 \\
\hline
\end{tabular}

The government communicated clearly to ensure that everyone had the information they needed to protect themselves and others from COVID-19, regardless of socioeconomic level, migrant status, ethnicity or language.

\begin{tabular}{lll|} 
Completely agree & 3216 & 24.0 \\
\hline Somewhat agree & 4534 & 33.8 \\
\hline Neutral/no opinion & 1936 & 14.4 \\
Somewhat disagree & 2071 & 15.4 \\
Completely disagree & 1666 & 12.4
\end{tabular}

The government made sure we always had full access to the healthcare services we needed during the epidemic.

$\begin{array}{lll}\text { Completely agree } & 2650 & 19.7 \\ \text { Somewhat agree } & 3901 & 29.1 \\ \text { Neutral/no opinion } & 2195 & 16.4 \\ \text { Somewhat disagree } & 2428 & 18.1 \\ \text { Completely disagree } & 2249 & 16.8\end{array}$

The government provided special protection to vulnerable groups at higher risk such as the elderly, the poor, migrants, prisoners and the homeless during the COVID-19 epidemic.

Completely agree 201015.0

Continued 


\begin{tabular}{lll}
\hline Table 1 Continued & N & $\%$ \\
\hline & 3746 & 27.9 \\
\hline Somewhat agree & 2446 & 18.2 \\
Neutral/no opinion & 2636 & 19.6 \\
Somewhat disagree & 2585 & 19.3 \\
Completely disagree & & \\
The government provided mental health services to help people \\
suffering from loneliness, depression and anxiety caused by the \\
COVID-19 epidemic. & \\
\hline Completely agree & 2931 & 21.9 \\
Somewhat agree & 3437 & 26.6 \\
\hline Neutral/no opinion & 2557 & 19.0 \\
\hline Somewhat disagree & 3007 & 22.4 \\
Completely disagree & & \\
\hline
\end{tabular}

Nearly $60 \%$ of the respondents said that their country's government had communicated clearly enough to ensure that everyone had the information they needed to protect themselves and others from COVID-19, a finding that was consistent regardless of the respondent's socioeconomic level, migrant status, ethnicity or language. More favourable evaluations of governmental response were reported by males and those with higher income levels (US\$8-US\$32 and US\$32+, tables 2 and 3). Nearly $8 \%$ of response variation (measured by the VPC) was due to differences between countries, with most positive responses reported in China $(83.4 \%)$ and least positive responses reported in Brazil (37.2\%, figure 1).

Almost half $(48.8 \%)$ of all respondents agreed that their government had made sure individuals always had full access to the healthcare services needed during the epidemic. Positive responses were reported more frequently by younger (18-29) and high income (US\$32+) individuals. Singapore $(83.9 \%)$ and China $(83.8 \%)$ had the highest proportion of positive responses while Poland $(27.2 \%)$, Russia (28.8\%) and Brazil $(29.0 \%)$ reported the lowest proportion of positive responses $(\mathrm{VPC}=14.5 \%)$.

Outcomes in respect to mental health services were much less positive. Less than a third $(32.9 \%)$ of all respondents agreed that their government had provided adequate support to people suffering from loneliness, depression and anxiety caused by the COVID-19 pandemic. More positive responses were associated with younger age (18-29). The highest frequency of positive responses was reported in China $(74.8 \%)$ and least positive responses were reported in Brazil (14.9\%) and Sweden $(15.5 \%)$ (VPC $=12.9 \%)$.

About two in five $(39.7 \%)$ respondents said the government had helped individuals and families meet daily needs for income, food and shelter during the COVID-19 pandemic. More positive responses were reported by younger (18-29), better-paid (US\$32+) and bettereducated individuals. A fairly substantial, $15 \%$, response variation on this question was attributed to intercountry differences. The country reporting the most positive responses was China $(79.0 \%)$, while the least positive responses were reported in Ecuador (14.6\%).

A slightly higher proportion $(42.9 \%)$ of all respondents agreed that their government had provided special protections to vulnerable groups at higher risk such as the elderly, the poor, migrants, prisoners and the homeless during the COVID-19 epidemic. Positive responses were associated with younger age (18-29), high income level (US\$32+) and very high education level. The most positive responses were reported in Singapore $(75.4 \%)$ and China $(75.0 \%)$ and least positive responses were reported in Sweden $(19.5 \%)(\mathrm{VPC}=10.8 \%)$.

\section{DISCUSSION}

This was the first large, multicountry study, to our knowledge, to assess to what degree respondents' age, gender, economic level and education were associated with perceptions of governmental effectiveness in meeting essential public health needs during the COVID-19 pandemic. $^{6}$

Over half of the respondents perceived their government to have communicated information adequately to the public, which was the most positive assessment given to any of the five factors assessed here. Approximately half of the respondents reported that their government had ensured individuals full access to the healthcare services they needed during the pandemic. Somewhat less positive perceptions were observed relative to the remaining three questions, with less than half saying that special protections to vulnerable groups at higher risk and assistance for families to meet daily needs were adequate. The least positive perception $(32.9 \%)$ was reported in respect to the provision of mental health services to those suffering from loneliness, depression and anxiety due to the COVID-19 pandemic.

The results show a wide range of positive responses to these five questions $(32.9 \%-57.8 \%)$ and a variation in the association of demographic factors across the five domains studied. There was a narrow range of variation attributed to intercountry variations in responses; the highest observed was in the perception of governments' ability to meet the daily needs of the population (15\%) and the lowest variation attributable to intercountry differences was in regard to governments' perceived ability to communicate effectively $(8 \%)$. This finding in itself is notable as $85 \%$ or more of the variation among a global population's responses on perception on the five domains assessed in this study was independent of country of residence.

Management of COVID-19 is complex and requires an evidence-based multifactorial approach supported by public engagement and trust. ${ }^{23}$ Many health systems remain overburdened with the ongoing spread of the virus, and thus community interventions are critical to engage with the general population. Clear communication and public trust in pandemic control measures are essential to ensure compliance with government 
Table 2 ORs for univariable associations when controlling for country

Univariate regression ( $95 \% \mathrm{Cls}) \quad$ Regression controlled for country via random effects $(95 \% \mathrm{Cls})$

Question: The government helped me and my family meet our daily needs during the COVID-19 epidemic in terms of income, food and shelter. Age (years)

$$
\begin{gathered}
30-60 \text { vs } 18-29 \\
1.14(1.05,1.23) \\
61+\text { vs } 18-29
\end{gathered}
$$

$30-60$ vs $18-29$

$1.00(0.91,1.09)$

$0.89(0.80,1.00)$

\begin{tabular}{|c|c|c|}
\hline Gender & $\begin{array}{l}\text { Male vs female } \\
0.92(0.86,0.99)\end{array}$ & $\begin{array}{l}\text { Male vs female } \\
0.92(0.85,0.99)\end{array}$ \\
\hline \multirow[t]{2}{*}{ Income } & $\begin{array}{l}\text { US } \$ 8-\text { US } \$ 32 \text { vs US\$0-US\$8 } \\
1.25(1.08,1.44)\end{array}$ & $\begin{array}{l}\text { US } \$ 8-\text { US } \$ 32 \text { vs US } \$ 0-U S \$ 8 \\
1.10(0.94,1.29)\end{array}$ \\
\hline & $\begin{array}{l}\text { US } \$ 32+\text { vs US } \$ 0-\text { US } \$ 8 \\
2.05(1.80,2.33)\end{array}$ & $\begin{array}{l}\text { US } \$ 32+\text { vs US } \$ 0-\text { US } \$ 8 \\
1.40(1.19,1.65)\end{array}$ \\
\hline \multirow[t]{3}{*}{ Education } & $\begin{array}{l}\text { Medium vs low } \\
1.25(1.15,1.37)\end{array}$ & $\begin{array}{l}\text { Medium vs low } \\
1.14(1.03,1.26)\end{array}$ \\
\hline & $\begin{array}{l}\text { High vs low } \\
1.35(1.23,1.48)\end{array}$ & $\begin{array}{l}\text { High vs low } \\
1.27(1.14,1.42)\end{array}$ \\
\hline & $\begin{array}{l}\text { Very high vs low } \\
1.61(1.41,1.83)\end{array}$ & $\begin{array}{l}\text { Very high vs low } \\
1.48(1.27,1.71)\end{array}$ \\
\hline
\end{tabular}

$61+$ vs $18-29$

$0.78(0.69,0.89)$

Question: The government communicated clearly to ensure that everyone had the information they needed to protect themselves and others from COVID-19, regardless of socioeconomic level, migrant status, ethnicity or language.

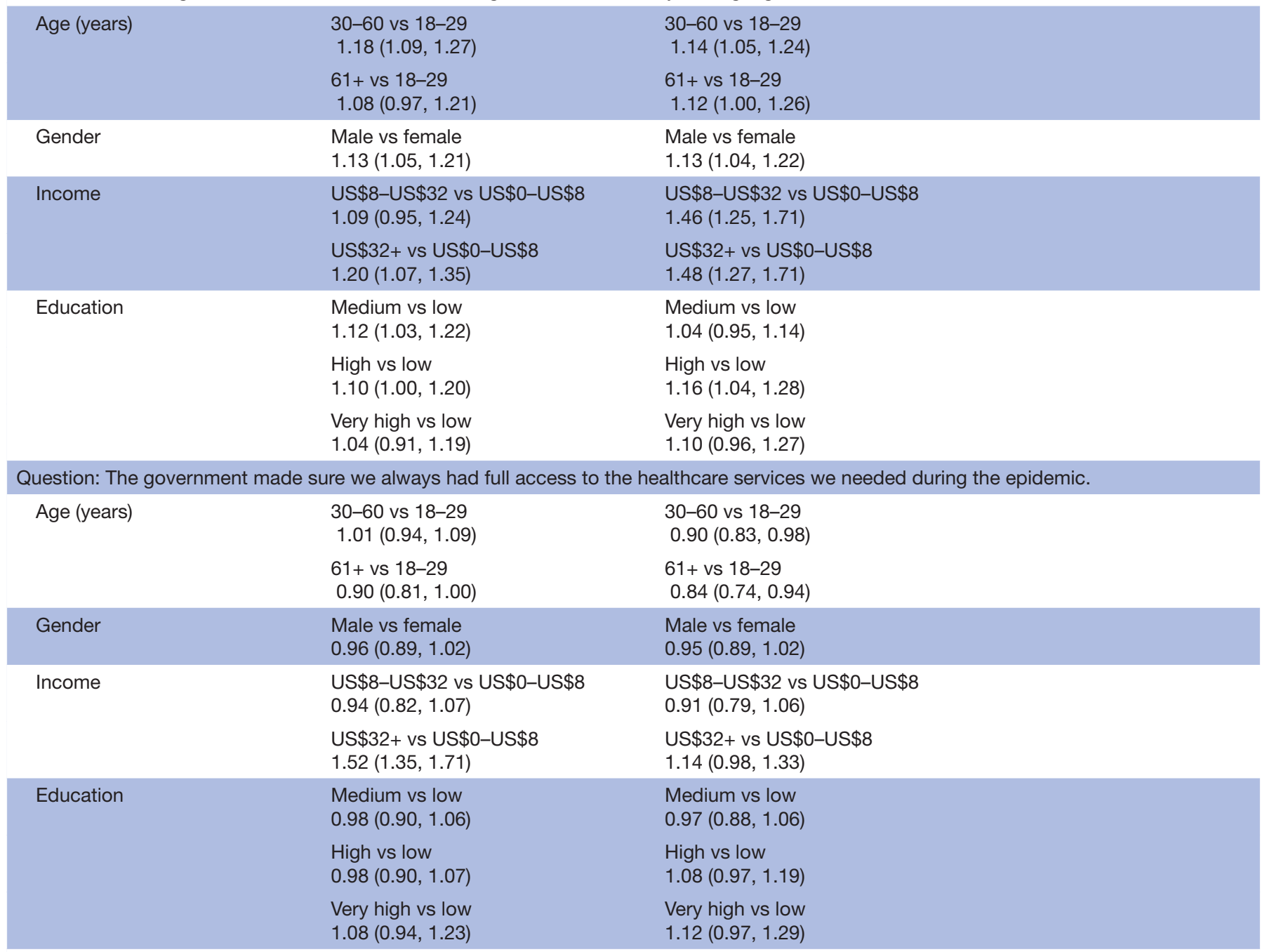

Question: The government provided special protections to vulnerable groups at higher risk such as the elderly, the poor, migrants, prisoners and the homeless during the COVID-19 epidemic. 
Table 2 Continued

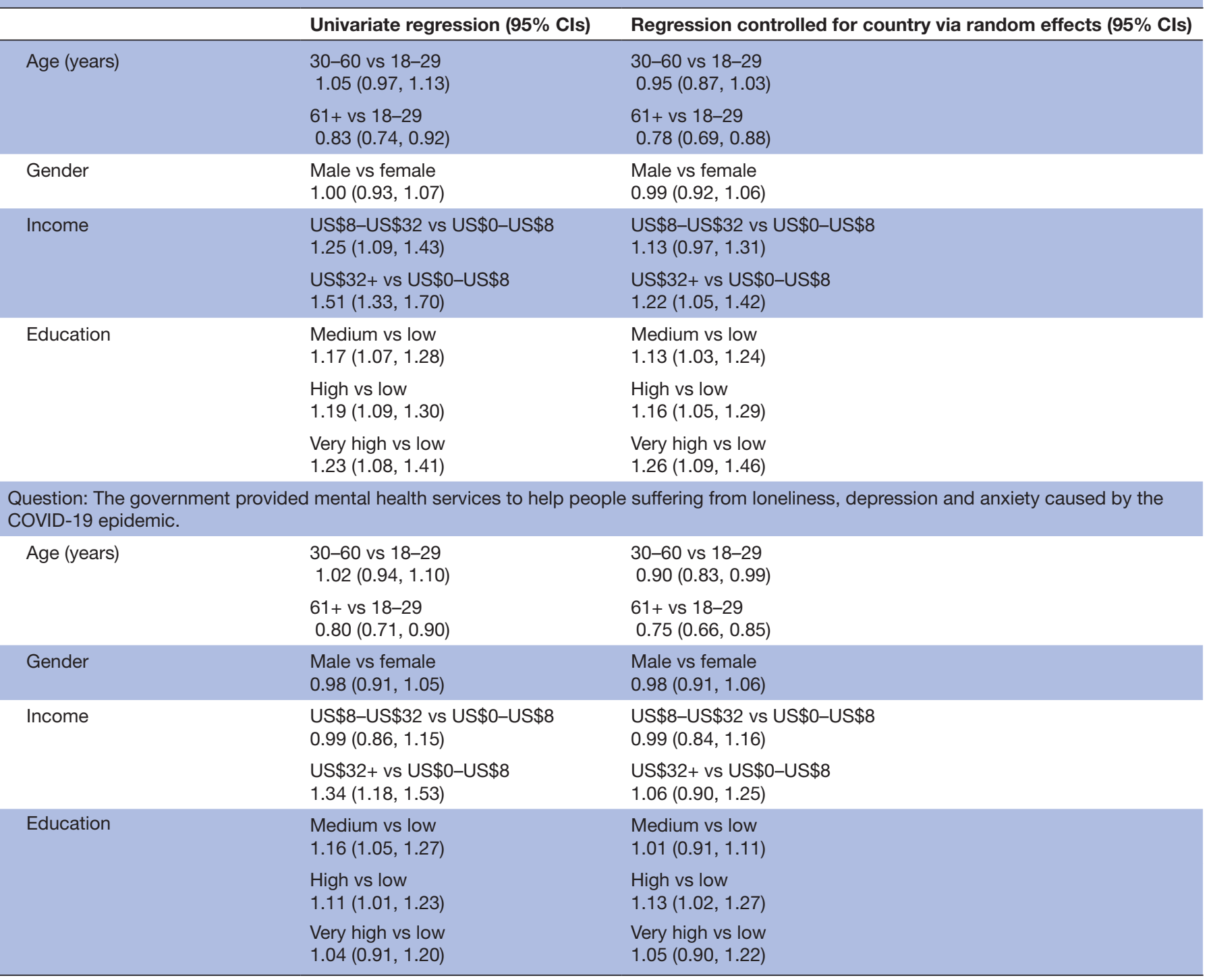

mitigation strategies and effectively reduce this burden. ${ }^{30}$ However, different groups in society (eg, women and men, older and younger people, the wealthy and the poor, persons with disabilities, children, single parents, minority groups, etc) are all affected differently and to varying degrees. While governments are working on the implementation of effective control measures, the spread of the virus continues to increase and its impact continues to fall disproportionately on vulnerable populations, who have less access to services and who as 'essential workers' are exposed to the virus in transit or at work. ${ }^{31} 32$ Further, the intersectional implications of the COVID-19 pandemic have exacerbated existing structural inequalities, in particular for women from marginalised groups. ${ }^{33}$

Indeed, advanced age, lower educational attainment and lower income were all associated with a less positive perception across the majority of the five questions analysed in this study. While younger, lower-income workers are more likely to have lost their job due to COVID19 , education is shown to be protective among young people, in addition to their reduced medical vulnerability to the virus relative to older individuals. ${ }^{34}$ Therefore, it is unsurprising that regardless of a respondent's country of residence, those with lower levels of education and income consistently perceived their governments' actions to ensure their daily needs of income, food and shelter to be inadequate. Conversely, only the highest income tier reported that their country's healthcare services have been fully accessible during the pandemic. This is expected given that wealthier individuals have better access to communication channels and may be in a better position to adapt to job insecurity and financial hardships, and thus require less governmental assistance. ${ }^{35}$ The pandemic has amplified inequalities and widened the gap between the rich and the poor; existing social protection systems may be inadequate to support vulnerable populations due to limited effectiveness and often complex eligibility restrictions. ${ }^{36}$ It is important to ensure the ability of disenfranchised and disempowered populations to access services whether through universal 
Table 3 ORs for multivariable associations when controlling for country

\section{Multivariable regression (95\% Cls) \\ Multivariable regression controlled for country via random effects $(95 \% \mathrm{Cls})$}

Question: The government helped me and my family meet our daily needs during the COVID-19 epidemic in terms of income, food and shelter.

\begin{tabular}{lll} 
Age (years) & $30-60$ vs $18-29$ & $30-60$ vs $18-29$ \\
& $1.00(0.92,1.08)$ & $0.95(0.87,1.04)$ \\
& $61+$ vs $18-29$ & $61+$ vs $18-29$ \\
Gender & $0.78(0.70,0.88)$ & $0.77(0.67,0.87)$ \\
\hline Income & Male vs female & Male vs female \\
& $0.94(0.88,1.02)$ & $0.94(0.87,1.03)$ \\
& US $\$ 8-$ US $\$ 32$ vs US $\$ 0-$ US $\$ 8$ & US $\$ 8-$ US $\$ 32$ vs US $\$ 0-U S \$ 8$ \\
Education & $1.25(1.08,1.45)$ & $1.10(0.93,1.30)$ \\
& US $\$ 32+$ vs US $\$ 0-U S \$ 8$ & US $\$ 32+$ vs US $\$ 0-U S \$ 8$ \\
& $2.04(1.78,2.33)$ & $1.37(1.15,1.63)$ \\
& Medium vs low & Medium vs low \\
& $1.20(1.09,1.32)$ & $1.08(0.97,1.20)$ \\
& High vs low & High vs low \\
& $1.21(1.09,1.33)$ & $1.18(1.05,1.32)$ \\
& Very high vs low & Very high vs low \\
& $1.33(1.16,1.53)$ & $1.37(1.18,1.60)$ \\
\hline
\end{tabular}

Question: The government communicated clearly to ensure that everyone had the information they needed to protect themselves and others from COVID-19, regardless of socioeconomic level, migrant status, ethnicity or language.

\begin{tabular}{|c|c|c|}
\hline \multirow[t]{2}{*}{ Age (years) } & $\begin{array}{l}30-60 \text { vs } 18-29 \\
1.11(1.02,1.20)\end{array}$ & $\begin{array}{l}30-60 \text { vs } 18-29 \\
1.07(0.98,1.17)\end{array}$ \\
\hline & $\begin{array}{l}61+\text { vs } 18-29 \\
1.00(0.90,1.12)\end{array}$ & $\begin{array}{l}61+\text { vs } 18-29 \\
1.06(0.93,1.20)\end{array}$ \\
\hline Gender & $\begin{array}{l}\text { Male vs female } \\
1.15(1.07,1.24)\end{array}$ & $\begin{array}{l}\text { Male vs female } \\
1.16(1.07,1.26)\end{array}$ \\
\hline \multirow[t]{2}{*}{ Income } & $\begin{array}{l}\text { US } \$ 8-\text { US } \$ 32 \text { vs US } \$ 0-\text { US } \$ 8 \\
1.02(0.89,1.17)\end{array}$ & $\begin{array}{l}\text { US } \$ 8-\text { US } \$ 32 \text { vs US } \$ 0-\text { US } \$ \$ 8 \\
1.34(1.15,1.56)\end{array}$ \\
\hline & $\begin{array}{l}\text { US } \$ 32+\text { vs US } \$ 0-\$ 8 \\
1.12(1.00,1.27)\end{array}$ & $\begin{array}{l}\text { US } \$ 32+\text { vs US } \$ 0-\text { US } \$ 8 \\
1.39(1.19,1.63)\end{array}$ \\
\hline \multirow[t]{3}{*}{ Education } & $\begin{array}{l}\text { Medium vs low } \\
1.09(0.99,1.19)\end{array}$ & $\begin{array}{l}\text { Medium vs low } \\
0.99(0.89,1.09)\end{array}$ \\
\hline & $\begin{array}{l}\text { High vs low } \\
1.04(0.94,1.14)\end{array}$ & $\begin{array}{l}\text { High vs low } \\
1.09(0.97,1.21)\end{array}$ \\
\hline & $\begin{array}{l}\text { Very high vs low } \\
0.99(0.86,1.13)\end{array}$ & $\begin{array}{l}\text { Very high vs low } \\
1.06(0.91,1.24)\end{array}$ \\
\hline \multicolumn{3}{|c|}{ Question: The government made sure we always had full access to the healthcare services we needed during the epidemic. } \\
\hline \multirow[t]{2}{*}{ Age (years) } & $\begin{array}{l}30-60 \text { vs } 18-29 \\
0.91(0.84,0.98)\end{array}$ & $\begin{array}{l}30-60 \text { vs } 18-29 \\
0.85(0.77,0.93)\end{array}$ \\
\hline & $\begin{array}{l}61+\text { vs } 18-29 \\
0.77(0.69,0.86)\end{array}$ & $\begin{array}{l}61+\text { vs } 18-29 \\
0.78(0.69,0.89)\end{array}$ \\
\hline Gender & $\begin{array}{l}\text { Male vs female } \\
0.97(0.90,1.04)\end{array}$ & $\begin{array}{l}\text { Male vs female } \\
0.97(0.89,1.05)\end{array}$ \\
\hline \multirow[t]{2}{*}{ Income } & $\begin{array}{l}\text { US } \$ 8-U S \$ 32 \text { vs US } \$ 0-U S \$ 8 \\
0.96(0.84,1.09)\end{array}$ & $\begin{array}{l}\text { US } \$ 8-\text { US } \$ 32 \text { vs US\$0-US\$8 } \\
0.92(0.79,1.08)\end{array}$ \\
\hline & $\begin{array}{l}\text { US } \$ 32+\text { vs US } \$ 0-U S \$ 8 \\
1.58(1.40,1.79)\end{array}$ & $\begin{array}{l}\text { US } \$ 32+\text { vs US } \$ 0-\text { US } \$ 8 \\
1.18(1.01,1.39)\end{array}$ \\
\hline
\end{tabular}

Continued 
Table 3 Continued

Multivariable regression (95\% Cls)

$\begin{array}{ll}\text { Education } & \text { Medium vs low } \\ & 0.95(0.87,1.04) \\ & \text { High vs low } \\ & 0.88(0.80,0.97) \\ & \text { Very high vs low } \\ & 0.94(0.82,1.08)\end{array}$

Multivariable regression controlled for country via random effects $(95 \%$ Cls)

Medium vs low
$0.94(0.85,1.04)$
High vs low
$1.01(0.90,1.13)$
Very high vs low
$1.08(0.93,1.26)$

Question: The government provided special protections to vulnerable groups at higher risk such as the elderly, the poor, migrants, prisoners and the homeless during the COVID-19 epidemic.

\begin{tabular}{|c|c|c|}
\hline \multirow[t]{2}{*}{ Age (years) } & $\begin{array}{l}30-60 \text { vs } 18-29 \\
0.98(0.90,1.06)\end{array}$ & $\begin{array}{l}30-60 \text { vs } 18-29 \\
0.91(0.84,1.00)\end{array}$ \\
\hline & $\begin{array}{l}61+\text { vs } 18-29 \\
0.78(0.68,0.85)\end{array}$ & $\begin{array}{l}61+\text { vs } 18-29 \\
0.76(0.67,0.86)\end{array}$ \\
\hline Gender & $\begin{array}{l}\text { Male vs female } \\
1.00(0.93,1.08)\end{array}$ & $\begin{array}{l}\text { Male vs female } \\
1.00(0.92,1.08)\end{array}$ \\
\hline \multirow[t]{2}{*}{ Income } & $\begin{array}{l}\text { US } \$ 8-\text { US } \$ 32 \text { vs US } \$ 0-U S \$ 8 \\
1.24(1.08,1.43)\end{array}$ & $\begin{array}{l}\text { US } \$ 8-\text { US } \$ 32 \text { vs US } \$ 0-U S \$ 8 \\
1.13(0.97,1.32)\end{array}$ \\
\hline & $\begin{array}{l}\text { US } \$ 32+\text { vs US } \$ 0-\text { US } \$ 8 \\
1.51(1.33,1.71)\end{array}$ & $\begin{array}{l}\text { US } \$ 32+\text { vs US } \$ 0-\text { US } \$ 8 \\
1.21(1.03,1.43)\end{array}$ \\
\hline \multirow[t]{3}{*}{ Education } & $\begin{array}{l}\text { Medium vs low } \\
1.22(1.03,1.23)\end{array}$ & $\begin{array}{l}\text { Medium vs low } \\
1.09(0.98,1.20)\end{array}$ \\
\hline & $\begin{array}{l}\text { High vs low } \\
1.08(0.98,1.19)\end{array}$ & $\begin{array}{l}\text { High vs low } \\
1.08(0.97,1.21)\end{array}$ \\
\hline & $\begin{array}{l}\text { Very high vs low } \\
1.10(0.95,1.26)\end{array}$ & $\begin{array}{l}\text { Very high vs low } \\
1.20(1.03,1.40)\end{array}$ \\
\hline \multicolumn{3}{|c|}{$\begin{array}{l}\text { Question: The government provided mental health services to help people suffering from loneliness, depression and anxiety } \\
\text { caused by the COVID-19 epidemic. }\end{array}$} \\
\hline \multirow[t]{2}{*}{ Age (years) } & $\begin{array}{l}30-60 \text { vs } 18-29 \\
0.95(0.87,1.04)\end{array}$ & $\begin{array}{l}30-60 \text { vs } 18-29 \\
0.88(0.80,0.97)\end{array}$ \\
\hline & $\begin{array}{l}61+\text { vs } 18-29 \\
0.73(0.64,0.82)\end{array}$ & $\begin{array}{l}61+\text { vs } 18-29 \\
0.73(0.64,0.84)\end{array}$ \\
\hline Gender & $\begin{array}{l}\text { Male vs female } \\
0.99(0.91,1.06)\end{array}$ & $\begin{array}{l}\text { Male vs female } \\
0.98(0.90,1.07)\end{array}$ \\
\hline \multirow[t]{2}{*}{ Income } & $\begin{array}{l}\text { US } \$ 8-U S \$ 32 \text { vs US } \$ 0-U S \$ 8 \\
1.02(0.89,1.19)\end{array}$ & $\begin{array}{l}\text { US } \$ 8-\text { US } \$ 32 \text { vs US } \$ 0-\text { US } \$ 8 \\
1.01(0.86,1.20)\end{array}$ \\
\hline & $\begin{array}{l}\text { US } \$ 32+\text { vs US } \$ 0-\text { US } \$ 8 \\
1.43(1.25,1.63)\end{array}$ & $\begin{array}{l}\text { US } \$ 32+\text { vs US } \$ 0-\text { US } \$ 8 \\
1.10(0.92,1.31)\end{array}$ \\
\hline \multirow[t]{3}{*}{ Education } & $\begin{array}{l}\text { Medium vs low } \\
1.12(1.03,1.24)\end{array}$ & $\begin{array}{l}\text { Medium vs low } \\
0.99(0.88,1.10)\end{array}$ \\
\hline & $\begin{array}{l}\text { High vs low } \\
1.01(0.92,1.13)\end{array}$ & $\begin{array}{l}\text { High vs low } \\
1.08(0.96,1.21)\end{array}$ \\
\hline & $\begin{array}{l}\text { Very high vs low } \\
0.91(0.79,1.06)\end{array}$ & $\begin{array}{l}\text { Very high vs low } \\
0.99(0.84,1.17)\end{array}$ \\
\hline
\end{tabular}

coverage or special emergency plans for expanded eligibility of coverage, or through economic stimulus plans, unemployment relief programmes, welfare and health safeguards and mechanisms to decrease out-of-pocket health spending by vulnerable groups. ${ }^{37}$

A 24-hour media environment has surrounded the COVID-19 pandemic throughoutitsduration, including TV and radio broadcasts, press briefings, official government websites and social media sites. ${ }^{38}$ Though this multimedia communication has resulted in unprecedented coverage volume, approaches have been uncoordinated,$^{38}$ and in several instances inconsistent, contradictory and misinformation has instilled confusion, ${ }^{39}$ panic and social disruption among the public, consequently weakening efforts to mitigate the outbreaks. ${ }^{14} 4041$ Our analysis showed that the least educated and poorest respondents rated 

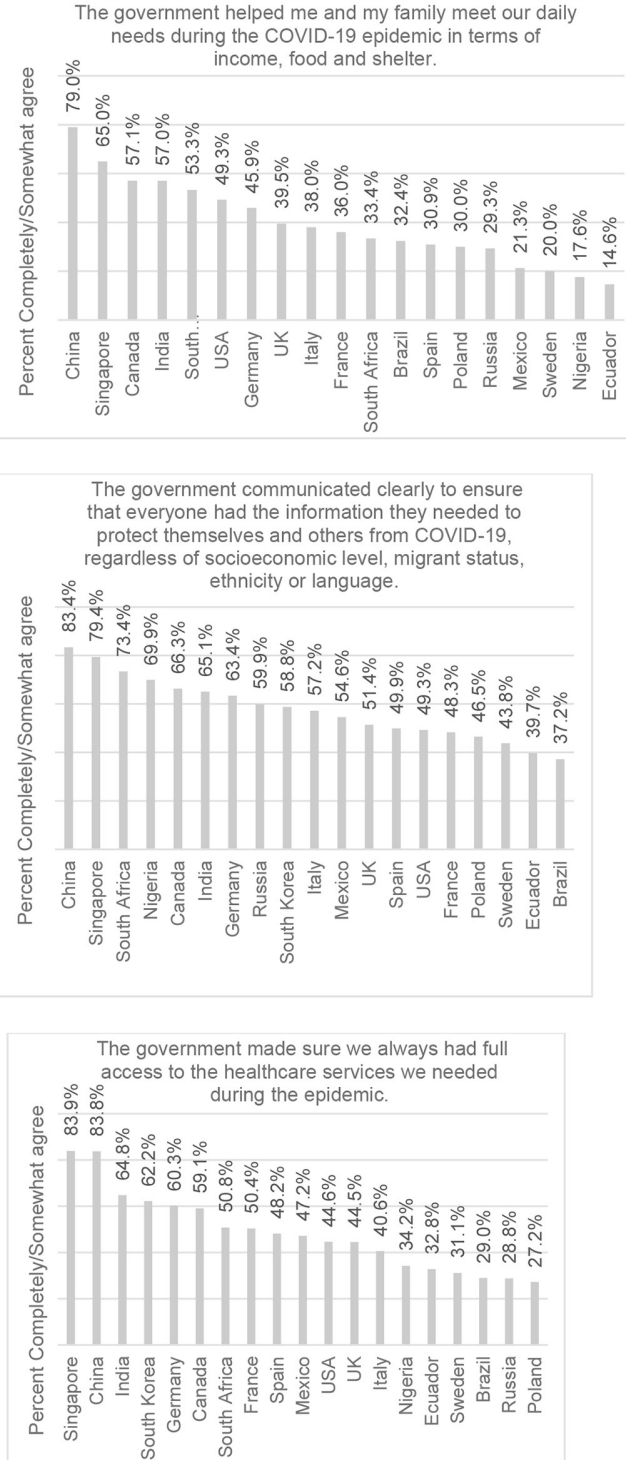
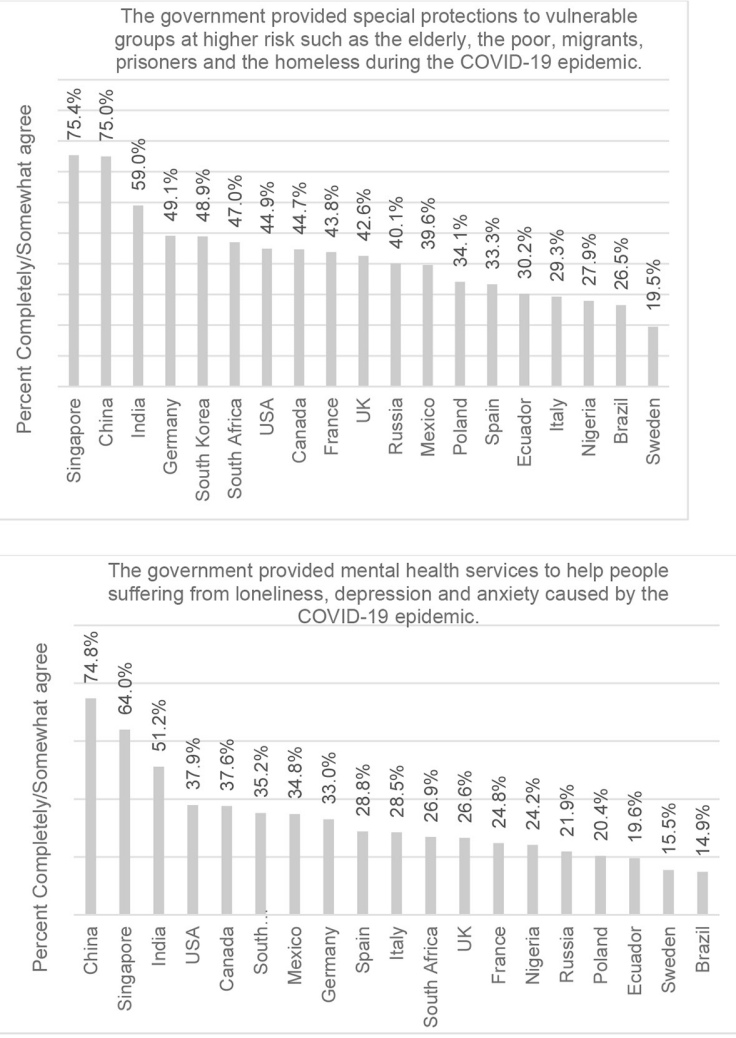

the clarity and adequacy of government communication on COVID-19 less positively. Responsiveness to health messaging is strongly influenced by media access, with the most vulnerable having the least access and generally the least opportunity to take protective actions (eg, teleworking). ${ }^{42}$ Women and younger respondents were also less satisfied with the existing communication strategies compared with men and older people, respectively. These differences are important in the next generation of media campaigns, which should be mindful of gender and age-specific messaging.

Our findings can assist decision-makers in improving their response to the pandemic as inequities in COVID-19 disease outcomes will ultimately be amplified by mediainduced dissonance and polarising messages. ${ }^{39}$ Authoritative and trustworthy information sources, with clear, understandable and consistent messaging are associated with greater compliance with preventive measures. ${ }^{43}$ Governments should ensure transparency, consistency, comprehensibility, coordination and community engagement while also monitoring the impact of multiple media outlets. ${ }^{38} 4144$ Governments and public health authorities should also strive to communicate proactively, establish trusted leadership, fight false information, ${ }^{45}$ provide proper interpretation of scientific evidence, promote health literacy and practice political accountability. ${ }^{41}$ We strongly recommend the implementation of media campaigns with key messaging, given that effective health and risk communication can encourage health-protective behaviours among the public, in respect to hygiene practices, the use of facemasks and social distancing as well as in general preventive health actions such as vaccination. Key messages may include, for example, "my doctor showed me why it really helps to wear a facemask and taught me the right way to use one' or 'the nurse at my clinic explained why vaccination is the best and fastest way to get our lives back to normal'.

The COVID-19 pandemic has exacerbated existing social and economic inequalities with respect to several non-communicable diseases, such as diabetes, asthma 
and hypertension, and underscored inequalities in the social determinants of health, which has led to disparities in COVID-19 infection and mortality rates. This issue is syndemic for the most disadvantaged populations, as mutually enhancing health and non-health problems affect the overall health status of the population and individual. ${ }^{46}$ Vulnerable groups are susceptible to poorer health and are disproportionately affected during the COVID-19 pandemic; this includes the elderly (especially those with chronic conditions such as cardiovascular disease), the poor, migrants, people who are incarcerated and people who are homeless. ${ }^{47} 48$ In our survey, the oldest, poorest and least-educated respondents perceived the governments' protection of the most vulnerable during the pandemic less positively. Effective government responses must be inclusive with regard to containment and mitigation strategies, beginning with adequate communication and inclusive messaging (ie, tailored, health literate and available in different languages, modalities, transparent and wide reaching). Measures to ensure vulnerable populations are addressed may include free testing, facemasks and disinfectant gel, access to clean water for handwashing, adequate access to health services or insurance benefits, social protection measures regardless of their legal status, employment rights (eg, paid sick leave) and accommodating marginalised groups in all cases with traditionally available sources of care close their physical locations. ${ }^{49}$ They may also include access to secured housing, food and sustenance for those with financial insecurity and securing the rights of asylum seekers and undocumented migrants. ${ }^{50}$ Health equity must be elevated on the public policy agenda to ensure inclusion regardless of age, socioeconomic level, education level, migrant status, ethnicity or language.

The experience of living through the COVID-19 pandemic and its associated government sanctions negatively influences the mental well-being of the population. ${ }^{51-53}$ Increases in the prevalence of anxiety and depression resulting from social isolation and loneliness, and concerns of financial difficulties and other implications of the pandemic have been observed. The lack of a positive response in the survey suggests that individuals did not feel supported during the pandemic. A recent study has shown that those who perceived a lack of emotional support during the COVID-19 pandemic are at an increased risk of anxiety and depression symptoms and thus, the inadequacy and/or lack of specialised mental healthcare during a pandemic should be addressed to ensure public confidence in the government. ${ }^{22} 54$ The need for mental health services and challenges to access have been recognised by others, particularly among vulnerable groups in low-income and middle-income countries (eg, those in poverty, those with financial insecurity, front-line workers and those suffering loss of employment) ${ }^{55-57}$ A previous study on public perceptions showed that those who believe that their government's response was insufficient suffered from lower mental well-being during the COVID-19 pandemic. ${ }^{58}$ Conversely, strong government actions (eg, regional and nationwide lockdowns, at the start of the pandemic) were linked to better mental well-being and an improvement in government perception, ${ }^{58}$ which can be attributed to, for example, the social connectedness experienced during a lockdown as this has been shown to buffer the effects of stress. ${ }^{51}$ Lack of efforts to address mental health challenges and restore well-being may impact future productivity and economic recovery, globally.

\section{Limitations}

This study has limitations that warrant mention. First, the stage of the pandemic in the respondent's country, as well as the respondent's personal experience with access to and quality of healthcare services, may well have influenced the perceived efficacy of government response to COVID-19. Second, differences in the forms or types of government that exist at national, regional and local levels in the 19 countries could make intercountry comparisons difficult to interpret. Indeed, some respondents may have feared that their government would illegally access their responses to our survey, which could also have skewed the findings. Third, the samples we surveyed may not adequately represent the most vulnerable populations in each country, as they would be less likely to be able to participate in social research of this type. Finally, this study is cross-sectional and was analysed descriptively, thus no causal inferences can be made.

\section{CONCLUSION}

This 19-country study found a high percentage of measurable variations across socioeconomic groups, independent of intercountry variation, with regard to respondents' perception of their government's response to the challenges of the COVID-19 pandemic. Advanced age, lower educational attainment and lower income were all associated with a less positive perception of an effective governmental response. Notably, the failure to provide adequate mental healthcare services and emotional support to the public must be addressed to achieve an effectual pandemic response. These findings should be taken into account as governments continue to seek to reduce the burden of COVID-19 and ultimately end the pandemic.

\section{Author affiliations}

${ }^{1}$ Barcelona Institute for Global Health (ISGlobal), Hospital Clínic, University of Barcelona, Barcelona, Spain

${ }^{2}$ Department of Epidemiology, University of Washington, Seattle, Washington, USA

${ }^{3}$ City University of New York (CUNY) Graduate School of Public Health \& Health Policy, New York, New York, USA

${ }^{4}$ Department of Epidemiology, Biostatistics and Occupational Health, McGill University, Montreal, Québec, Canada

${ }^{5}$ UCLA Fielding School of Public Health and Geffen School of Medicine, Los Angeles, California, USA

\section{Twitter Jeffrey V Lazarus @JVLazarus}

Acknowledgements JVL acknowledges support to ISGlobal from the Spanish Ministry of Science, Innovation and Universities through the 'Centre of Excellence Severo Ochoa 2019-2023' (CEX2018-000806-S) and support from the Government of Catalonia through the CERCA Programme. The funders had no role in this work.

Contributors AE-M, JVL and AP conceived of the study. Data analysis was led by KW and AP. JVL and SH drafted the first iteration of the manuscript with input 
from KR, AE-M, AP, KW, SR and JF. All authors reviewed the full draft of the article, subsequent revisions and approved the final version for submission.

Funding This work was supported via direct transfer from the research foundation budget of the City University of New York (CUNY) Graduate School of Public Health and Health Policy. In addition, funds were received directly from Dr Jonathan Fielding, the United States Council for International Business Foundation, Dr Kenneth Rabin and Bocconi University (Italy). The authors are solely responsible for all content, and non-authoring funders played no role in study design, data collection and analysis, decision to publish or preparation of the manuscript.

Competing interests None declared.

Patient and public involvement Patients and/or the public were not involved in the design, or conduct, or reporting or dissemination plans of this research.

Patient consent for publication Not required.

Provenance and peer review Not commissioned; externally peer reviewed.

Data availability statement Data are available upon request. Deidentified participant data are available from the corresponding author, Jeffrey V Lazarus (ORCID identifier: 0000-0001-9618-2299).

Open access This is an open access article distributed in accordance with the Creative Commons Attribution Non Commercial (CC BY-NC 4.0) license, which permits others to distribute, remix, adapt, build upon this work non-commercially, and license their derivative works on different terms, provided the original work is properly cited, appropriate credit is given, any changes made indicated, and the use is non-commercial. See: http://creativecommons.org/licenses/by-nc/4.0/.

\section{ORCID iD}

Jeffrey V Lazarus http://orcid.org/0000-0001-9618-2299

\section{REFERENCES}

1 Johns Hopkins Coronavirus Resource Center. COVID-19 map, 2020. Available: https://coronavirus.jhu.edu/map.html

2 Su D, Chen Y, He K, et al. Influence of socio-ecological factors on COVID-19 risk: a cross-sectional study based on 178 countries/ regions worldwide. medRxiv 2020. doi:10.2139/ssrn.3582852. [Epub ahead of print: 29 Apr 2020].

3 Haynes N, Cooper LA, Albert MA. Unmasking and addressing the toll of COVID-19 on diverse populations. J Am Heart Assoc 2020;142:105-7.

4 Hamidian Jahromi A, Hamidianjahromi A. Why African Americans are a potential target for COVID-19 infection in the United States. J Med Internet Res 2020;22:e19934.

5 Shah GH, Shankar P, Schwind JS, et al. The detrimental impact of the COVID-19 crisis on health equity and social determinants of health. J Public Health Manag Pract 2020;26:317-9.

6 Lazarus JV, Ratzan S, Palayew A, et al. COVID-SCORE: a global survey to assess public perceptions of government responses to COVID-19 (COVID-SCORE-10). PLoS One 2020;15:e0240011.

7 Hale T, Angrist N, Cameron-Blake E, et al. Variation in government responses to COVID-19, 2020. Available: www.bsg.ox.ac.uk/ covidtracker

8 WHO. European Observatory on health systems and policies, 2020. Available: https://analysis.covid19healthsystem.org/index.php/2020/ 05/19/how-do-measures-for-isolation-quarantine-and-contacttracing-differ-among-countries/

9 The Lancet. COVID-19: too little, too late? Lancet 2020;395:755.

10 Bedford J, Enria D, Giesecke J, et al. COVID-19: towards controlling of a pandemic. Lancet 2020;395:1015-8.

11 Liu W, Yue X-G, Tchounwou PB. Response to the COVID-19 epidemic: the Chinese experience and implications for other countries. Int J Environ Res Public Health 2020;17:2304.

12 Han E, Tan MMJ, Turk E, et al. Lessons learnt from easing COVID-19 restrictions: an analysis of countries and regions in Asia Pacific and Europe. Lancet 2020;396:1525-34.

13 Peeri NC, Shrestha N, Rahman MS, et al. The SARS, MERS and novel coronavirus (COVID-19) epidemics, the newest and biggest global health threats: what lessons have we learned? Int $J$ Epidemiol 2020;49:717-26.

14 Ruiu ML. Mismanagement of Covid-19: lessons learned from Italy. $J$ Risk Res 2020;23:1007-20.

15 WHO. SARS-CoV-2 variants, 2020. Available: www.who.int/csr/don/ 31-december-2020-sars-cov2-variants/en

16 Rambaut A, Loman N, Pybus O. Preliminary genomic characterisation of an emergent SARS-CoV-2 lineage in the UK defined by a novel set of spike mutations, 2020. Available: https:// virological.org/t/preliminary-genomic-characterisation-of-anemergent-sars-cov-2-lineage-in-the-uk-defined-by-a-novel-set-ofspike-mutations $/ 563$

17 Tuite AR, Greer AL, De Keninck S, et al. Risk for covid-19 resurgence related to duration and effectiveness of physical distancing in Ontario, Canada. Ann Intern Med 2020;173:675-8.

18 López L, Rodó X. The end of social confinement and COVID-19 reemergence risk. Nat Hum Behav 2020;4:746-55.

19 Hawkins D. Differential occupational risk for COVID-19 and other infection exposure according to race and ethnicity. Am J Med 2020:63:817-20.

20 Dryhurst S, Schneider CR, Kerr J, et al. Risk perceptions of COVID-19 around the world. J Risk Res 2020;23:994-1006.

21 Bavel JJV, Baicker K, Boggio PS, et al. Using social and behavioural science to support COVID-19 pandemic response. Nat Hum Behav 2020;4:460-71.

22 Moreno C, Wykes T, Galderisi S, et al. How mental health care should change as a consequence of the COVID-19 pandemic. Lancet Psychiatry 2020;7:813-24.

23 Shore DA. Communicating in times of uncertainty: the need for trust. $J$ Health Commun 2003;8 Suppl 1:13-14.

24 Douglas M, Katikireddi SV, Taulbut M, et al. Mitigating the wider health effects of covid-19 pandemic response. BMJ 2020;369:1557.

25 Gausman J, Langer A. Sex and gender disparities in the COVID-19 pandemic. J Womens Health 2020;29:465-6.

26 Landivar LC, Ruppanner L, Scarborough WJ, et al. Early signs indicate that COVID-19 is exacerbating gender inequality in the labor force. Socius 2020.

27 Shadmi E, Chen Y, Dourado I, et al. Health equity and COVID-19: global perspectives. Int J Equity Health 2020;19:104

28 Daoust J-F. Elderly people and responses to COVID-19 in 27 countries. PLOS One 2020;15:e0235590.

29 Gapminder. Income levels, 2020. Available: https://www.gapminder. org/fw/income-levels/

30 Ebrahim SH, Ahmed QA, Gozzer E, et al. Covid-19 and community mitigation strategies in a pandemic. BMJ 2020;368:m1066.

31 Gray DM, Anyane-Yeboa A, Balzora S, et al. COVID-19 and the other pandemic: populations made vulnerable by systemic inequity. Nat Rev Gastroenterol Hepatol 2020;17:520-2.

32 Patel JA, Nielsen FBH, Badiani AA, et al. Poverty, inequality and COVID-19: the forgotten vulnerable. Public Health 2020;183:110-1.

33 European Parliament. REPORT on the gender perspective in the COVID-19 crisis and post-crisis period (2020/2121(INI))., 2020. Available: https://www.europarl.europa.eu/doceo/document/A-92020-0229_EN.pdf

34 Blundell R, Costa Dias M, Joyce R, et al. COVID-19 and Inequalities*. Fisc Stud 2020;41:291-319.

35 Takian A, Kiani MM, Khanjankhani K. COVID-19 and the need to prioritize health equity and social determinants of health. Int $J$ Public Health 2020;65:521-3.

$36 \mathrm{Ku} \mathrm{L}$, Brantley E. Widening social and health inequalities during the COVID-19 pandemic. JAMA Health Forum 2020;1:e200721.

37 Lazarus JV, White TM, Hajo S, et al. How can we ensure a socially equitable approach to Deconfinement during the COVID-19 pandemic? 2020. Available: https://www.isglobal.org/en_GB/-/como-podemos-garantizar-un-enfoque-socialmente-equitativo-enel-desconfinamiento-

38 WHO. European Observatory on health systems and policies, 2020 Available: https://analysis.covid19healthsystem.org/index.php/2020/ 07/03/what-channels-are-countries-using-to-communicate-with-thepublic-and-at-what-frequency/

39 Yong E. Why the coronavirus is so confusing, 2020. Available: https:// www.theatlantic.com/health/archive/2020/04/pandemic-confusinguncertainty/610819/

40 Garrett L. COVID-19: the medium is the message. Lancet 2020;395:942-3.

41 Ratzan S, Sommariva S, Rauh L. Enhancing global health communication during a crisis: lessons from the COVID-19 pandemic. Public Health Res Pract 2020;30:e3022010.

42 Gollust SE, Nagler RH, Fowler EF. The emergence of COVID-19 in the US: a public health and political communication crisis. $J$ Health Polit Policy Law 2020;45:8641506.

43 Qazi A, Qazi J, Naseer K, et al. Analyzing situational awareness through public opinion to predict adoption of social distancing amid pandemic COVID-19. J Med Virol 2020;92:849-55.

44 World Health Organization. Risk communication and community engagement readiness and response to coronavirus disease (COVID-19): interim guidance, 19 March 2020. in: COVID-19: risk communication and community engagement. Geneva: World Health Organization, 2020. 
45 Government of Canada. COVID-19: social media and promotional resources for health Canada and public health agency of Canada, 2020. Available: https://www.canada.ca/en/public-health/services/ diseases/2019-novel-coronavirus-infection/digital-resources.html\#s2

46 Bambra C, Riordan R, Ford J, et al. The covid-19 pandemic and health inequalities. J. Epidemiol Community Health 2020;0:1-5.

47 Lloyd-Sherlock P, Ebrahim S, Geffen L, et al. Bearing the brunt of covid-19: older people in low and middle income countries. BMJ 2020;368:m1052.

48 The Lancet. Redefining vulnerability in the era of COVID-19. Lancet 2020;395:1089.

49 Berger ZD, Evans NG, Phelan AL, et al. Covid-19: control measures must be equitable and inclusive. BMJ 2020;368:m1141.

50 Weatherburn A, Gutwirth S, De Hert P. The fundamental rights impact of the measures taken to reduce the spread of Covid-19 on those living in poverty or in a precarious situation. in: societal exit from lockdown. Contribution of academic expertise 2020:62-5.

51 Sibley CG, Greaves LM, Satherley N, et al. Effects of the COVID-19 pandemic and nationwide lockdown on trust, attitudes toward government, and well-being. Am Psychol 2020;75:618-30.
52 Vigo D, Patten S, Pajer K, et al. Mental health of communities during the COVID-19 pandemic. Can J Psychiatry 2020;65:681-7.

53 Usher K, Durkin J, Bhullar N. The COVID-19 pandemic and mental health impacts. Int J Ment Health Nurs 2020;29:315-8.

54 van der Velden PG, Contino C, Das M, et al. Anxiety and depression symptoms, and lack of emotional support among the general population before and during the COVID-19 pandemic. A prospective national study on prevalence and risk factors. J Affect Disord 2020;277:540-8.

55 Holmes EA, O'Connor RC, Perry VH, et al. Multidisciplinary research priorities for the COVID-19 pandemic: a call for action for mental health science. Lancet Psychiatry 2020;7:547-60.

56 Kelly BD. Coronavirus disease: challenges for psychiatry. Br J Psychiatry 2020;217:352-3.

57 Mesa Vieira C, Franco OH, Gómez Restrepo C, et al. COVID-19: the forgotten priorities of the pandemic. Maturitas 2020;136:38-41.

58 Fetzer T, Witte M, Hensel L. Perceptions of an insufficient government response at the onset of the COVID-19 pandemic are associated with lower mental well-being. Boston: Harvard Business School, 2020. 